\title{
NAFTA trade (and some extra NAFTA trade) in value added and its distribution, 1995-2011
}

\author{
Rosario Cervantes-Martínez ${ }^{*}$ (], Jorge Villaseñor-Becerra and Martín Romero-Morett
}

\author{
*Correspondence: \\ mariac@cucea.udg.mx \\ Economics Department, \\ University Center \\ for Economic \\ and Administrative Sciences, \\ University of Guadalajara, \\ Módulo K-302, Periférico \\ Norte 799, Núcleo \\ Universitario Los Belenes, \\ C.P. 45100, Zapopan, Jalisco, \\ Mexico
}

\begin{abstract}
The trade deficit of the USA with its NAFTA partners, Mexico and Canada, increased since 1994 from 21,991 to 119,257 million dollars in 2013 (UNCOMTRADE, 2015. http:// comtrade.un.org/db), and most of this increase is explained by the growth in the volume of commerce between Mexico and the USA. Nonetheless, since the mid1990s Mexico has been experiencing its lowest economic growth rates. By using the World Input Output Database and the Input-Output Analysis, this paper presents an estimate of the intra-NAFTA trade flows in terms of value added and its distribution among both labor and capital; labor by skill level; and content of persons engaged. The findings show that trade between the NAFTA members is quite different concerning value added. In 1995 the USA had a trade deficit of 30,351 million dollars with Canada, of which 6384 million dollars was a surplus in favor of Canada in terms of value added. Similarly, the same year the USA had a deficit of 4276 million dollars with Mexico that became a surplus for the latter of 4561 million dollars in terms of value added. For the following years, until 2011, a similar pattern was observed. The distribution of this value added between capital and labor compensations tends to favor USA and Canadian workers, especially middle-skilled labor, and the sector that tends to have the lowest share is the low-skilled Mexican and Canadian workers. Even more, the average labor compensations per hour grew less for the three types of Mexican workers.
\end{abstract}

Keywords: Value added in trade, Income distribution, NAFTA

\section{Background}

On the first of January of 1994 the North American Free Trade Agreement (NAFTA) entered into effect, signed by Mexico, the USA, and Canada. With this treaty it was hoped that, particularly in Mexico, greater economic growth, employment, and wage rates would be observed. Today, after more than 20 years after the beginning of the agreement, the Mexican economy has not achieved greater growth rates, and in fact, they are below those observed during the 1950-1980 time period. Annual average growth rates for the 1950s, 1960s, and 1970s were around 6.5\%, and after the so-called lost decade of the 1980s, the higher annual average growth rate was the one observed in the $1990 \mathrm{~s}$ at $3.4 \%$, a decade in which the largest volume of foreign trade was achieved. ${ }^{1}$

\footnotetext{
${ }^{1}$ GDP growth rates for Mexico were calculated using World Bank data (2013).
}

( ) The Author(s) 2016. This article is distributed under the terms of the Creative Commons Attribution 4.0 International License (http://creativecommons.org/licenses/by/4.0/), which permits unrestricted use, distribution, and reproduction in any medium, provided you give appropriate credit to the original author(s) and the source, provide a link to the Creative Commons license, and indicate if changes were made. 
The literature on the reasons why the Mexican economy has lagged behind the expected growth rates dwells on the need of deeper reforms, but also on the possibility that it was the way the nation entered the world economy the fact that helps to explain the lack of economic performance of the latter years. From the analysis of the Global Value Chains (GVCs) and the way Mexico participates in them, this research estimates the domestic value added contained in trade flows between the NAFTA members, its distribution in labor and capital compensations, and its employment content (measured as the volume of persons engaged), in order to validate the second explanation given above, as one of the main reasons why Mexico's economic performance has not being as expected. The main goal is to show not only that, when the largest share of the volume of foreign trade is constituted by intermediate goods and raw materials, a double accounting problem in trade flows is observed, but also that production specialization and trade of goods with a low value-added content impose an additional restriction to the "exportled growth strategies" ${ }^{2}$ and that, through factorial distribution of income as a consequence of exports and median income, it can also be explained how exports growth did not contribute to the growth of the Mexican economy significantly.

The rest of the document is organized as follows: In Sect. 2, a brief literature review on the theoretical aspects of free trade advantages, free trade agreements, and trade evolution between the NAFTA members is made. Section 3 describes the method used in the estimation of the account balances of trade flows between the NAFTA members in terms of value added, its distribution as payments to factors of production, and its employment content. In Sect. 4, the estimation results for the total amount of value added, in both the intermediate and final goods trade flows, as well as its distribution in compensations to capital or labor, are reported. In Sect. 5 a brief balance of persons engaged, directly or indirectly, in the intra-NAFTA trade is made; also, some evidence of wider gaps in the average labor compensations per hour by skill level is showed. In the last section we conclude.

\subsection{Free trade, free trade agreements, and the evolution of NAFTA}

Since the publication of An Inquiry into the Nature and Causes of the Wealth of Nations by Adam Smith (2008, [1776]) it has been discussed that production specialization and free trade are both essential aspects for the better use of available and scarce resources. In an oversimplified way, it is supposed that, if every individual exclusively does what it does best, more production can be achieved and, through free trade, each participant obtains more and better goods and services than without such free trade. However, the economic systems in which goods and services are traded through monetary payments are complex systems in which, during the resource allocation; the production volume; and the price determination processes; multiple and dynamic relationships can be observed between buyers and producers of raw materials, capital and consumption goods, financial services and labor. The latter implies that in the development of free trade theory more elements that help understanding free trade advantages, at both an individual and economic system levels, functioning with different currencies, had to be introduced.

\footnotetext{
${ }^{2}$ In Giles and Williams (2000) can be found a survey of the extensive amount of empirical works measuring or validating the relationship between exports and economic growth.
} 
After Smith, David Ricardo, around 1821, introduces the concept of the comparative advantage in order to highlight that, even when a particular agent or economic system do not possess an absolute advantage, gains can still be obtained if each agent or system focuses on the production of that in which is relatively better at. Furthermore, in the first decades of the twentieth century, Eli Hecksher and Bertil Ohlin noticed that, when trade is present between economies, the relative endowments of factors of production and natural resources constitute the basis of trade advantages through relative prices of factors of production ${ }^{3}$ and of different forms of production that require a relatively more intensive use of any given factor, depending on the good being produced. From the latter, the Hecksher-Ohlin theorem is derived, according to which free trade advantages will also lead economies to a productive specialization. Such specialization is a consequence of economies being relatively labor-abundant produce more labor-intensive goods, while those economies with a relatively more abundant endowment of capital produce capital-intensive goods. Moreover, through the Leontief paradox and Paul Krugman's elaborations, among others, more elements were added to the analysis of international trade and its advantages, such as the possibility of allowing, besides labor and capital, specialized labor in the production of capital-intensive goods and the achievement of economies of scale, which would explain the benefits of free trade between countries with similar factors of production endowments and trade under imperfect competition settings.

On the other hand, in works by List (1997, [1841]) and Prebish (1949), arguments are put forward that are contrary to the idea that international trade without barriers is always advantageous for those economies involved. For List, free trade can represent a threat to the development of poor economies if such trade impairs the development of productive capabilities. That is, instead of considering trade as one of the causes of the "wealth of nations," the author argues that the main cause of the wealth of nations is the enhancement of domestic production, institutional and political processes that enable the achievement of wealth, so that once such wealth is achieved, through trade, more benefits can be obtained. From List's arguments on the need of protecting domestic industries, it can be thought of a dynamic version of the $\mathrm{H}-\mathrm{O}$ model that would allow the distinction between the assumption of "a given relative endowment of factors of production" and the assumptions on the conditions that allow the accumulation of such factors, particularly capital and human capital.

For Prebish, and the Latin-American structuralism (Rodriguez 2006), the deterioration of the terms of trade is a risk that developing economies face when participating in international trade with the more developed ones. From the latter, additional considerations are introduced into the forms of production, on both the supply and demand sides, that might affect the gains derived from trade. It is argued that, for example, a differentiated productivity growth of tradable goods would make median income to increase to a lesser rate than in those economies specialized in the production and commercialization of goods with a lower productivity growth rate (i.e., raw materials). Hence, trade advantages would not be obtained given lower levels of relative income. As for the demand side, different income elasticities of tradable goods demand would

${ }^{3}$ This is the Ricardian version of comparative advantage, explained by the unit labor cost as a determinant of labor productivity. 
make that the median income of the economies specialized in the production and commercialization of low demand-income elasticity goods or low demand-price elasticity of exports, but high-income elasticity of imports, explain why international trade gains can be lower for these economies when observing lower growth rates. Thus, by adding to the Kaldor-Dixon-Thirwall model (see Thirwall 2013) the elements from the deterioration of the terms of trade thesis, if productivity is a consequence of income growth (Verdoon Law) and income is conditional on the terms of trade, free trade could lead not only to a divergence process between developed and developing economies but to the economic stagnation of the latter. That is, in the non-static analysis of the consequences of trade liberalization, it must be considered which ones are the determinants of both productivity and income growth. The latter given that it is through income growth that companies guarantee their profits in order to achieve capital accumulation.

In the value-added content analysis made in Cervantes and Villaseñor (2014), following the Kaldor-Dixon-Thirwall model, it is also argued that distinguishing between the gross value of exports and the domestic value-added content in them allows for a better understanding of the conditions that must be attained in order for free trade, through exports growth, to translate into larger economic growth rates. Furthermore, it is also argued that the analysis of the benefits of free trade that focus on the idea of final goods trade is inadequate given the twenty-first century trade patterns, in which it is not only wine or cheese that its being traded, or just manufactured goods using raw materials, but goods that are used in many stages of the production process. That is, through the analysis of international trade in terms of value added (see OECD-WTO 2012 and Stehrer et al. 2013, and Gereffi 2013, among others) the estimation of the form in which the final value of finished goods is added, or the way in which the gains from trade are distributed in the form of payments to the factors of production, through direct or indirect trade of goods and services, is attempted. Moreover, for Gereffi (2013: 11) and Kaplinsky (2000), the new trade patterns derived from the growth of the global production nets (GPNs) and "the dynamics of profits in global value chains" had been associated with "growth in income inequality levels," both between individuals and between nations. And, it is possible that the distribution patterns that have led to this growth in inequality affect the conditions that allow increasing the domestic demand of the nations involved, through the consumption and demand of investment goods.

Regarding free trade agreements, it was in Mexico in the mid-1980s when the liberalization of the economic activity begun and would be the basis for the signing of 11 free trade agreements, of which only one has not come into force. The latter amount of treaties implies that Mexico has preferential trade agreements with more than 40 nations, including most of the largest economies in the world. However, by signing the General Agreement on Tariffs and Trade (GATT) in Mexico trade barriers and tariffs for imports were unilaterally and significantly reduced: Maximum and weighted average tariffs went from 100 and 23.5\% to 20 and 12.5\%, respectively, between June 1985 and June 1990; while the share of tradable goods production subject to import permits went from 92.2 to $19.9 \%$ in the same period (Clavijo and Valdivieso 2000: 16). Thus, the negotiations for the signing of NAFTA initiated when the nation had already made significant advancements in the liberalization of its foreign trade, the latter being for some authors, the proof that these kinds of treaties are more related to the integration processes of the 
production systems than with the free exchange of merchandise. As an example, Puyana (2003) suggests that NAFTA, the treaty with the European Union, and the free trade agreement with the European Free Trade Association are all projects that aim to achieve more freedom for foreign investment, which would also explain the way Mexico participates in the GVCs and the income distribution derived from exports.

Hence, with data from the WIOD, in gross terms, from 1995 to 2011, the trade balances between NAFTA members have been increasing in favor of surpluses for Canada and Mexico with the USA and of Mexico with Canada (see Fig. 1). In 1995 the exports surplus of Canada to the USA and of Mexico to the USA were of 30,351 and 4276 million dollars, respectively, while the surplus of Mexico with Canada was of 1692 million dollars. By 2011, the amounts increased to 66,414, 60,211, and 10,386 million dollars, respectively. As it can be observed, the more significant increases were those of in favor of the Mexican economy.

From Table 1 and Fig. 2, it can also be observed that, of the exports between the NAFTA members, in average, $60 \%$ is of intermediate goods. And, during the whole period, the USA is the largest exporter of intermediate goods with, approximately, $44 \%$ of the total exports and $63.5 \%$ of its total exports. However, the trade balances change when breaking down these two exports categories. Particularly, from 1995 to 2003, Mexico had a deficit in trade of intermediate goods with the USA, while from 2003 onward most of the surplus of Canada would be explained by the surplus derived from the trade of intermediate goods with the USA.

By the type of product at industry level, Table 2 shows that, in average, from 1995 to 2001 between the three nations, the greater volume of trade is concentrated in exports of manufactured goods. However, for the USA, almost half of its total exports to its commercial partners are in the form of intermediate goods from manufacturing industries, particularly high-technology goods. Mexico is also the nation in which raw materials exports are higher, in the form of both intermediate and final goods. As for Canada, the

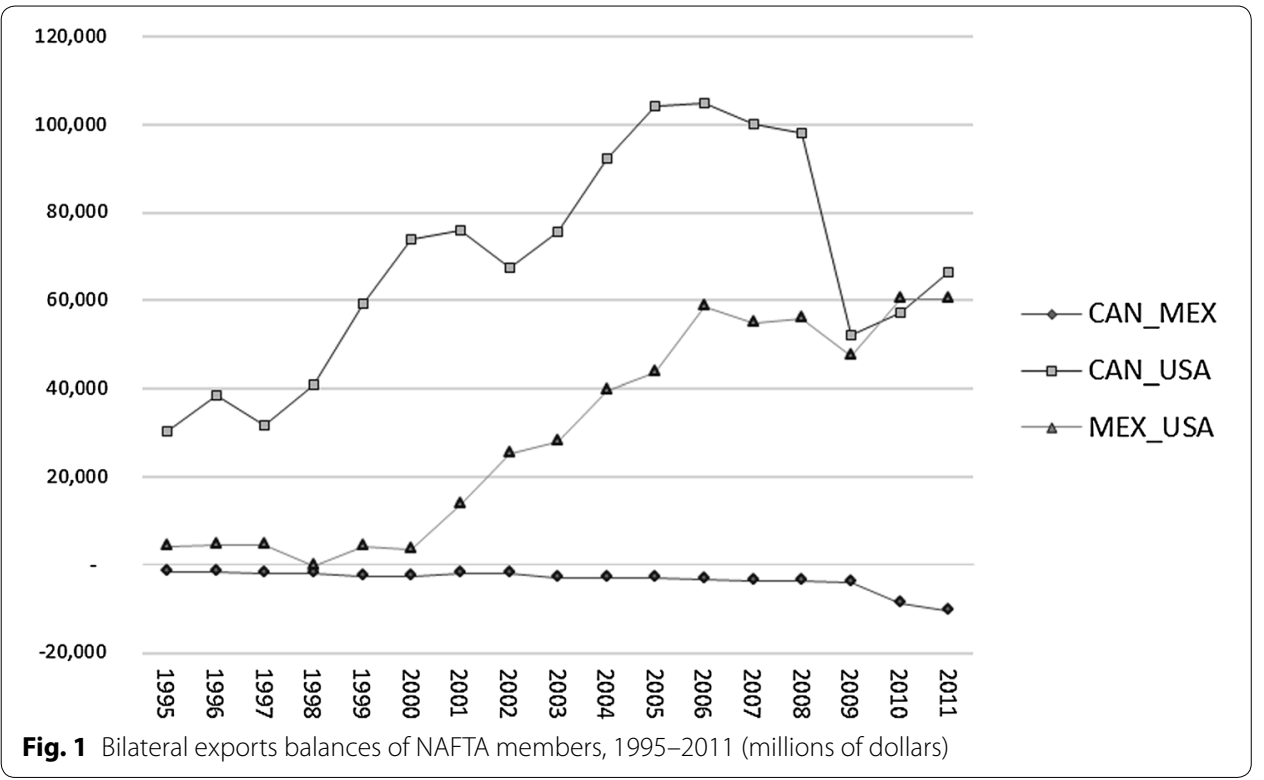


Table 1 Intra-NAFTA exports by type of product, 1995-2011 Source Authors' estimations based on WIOD

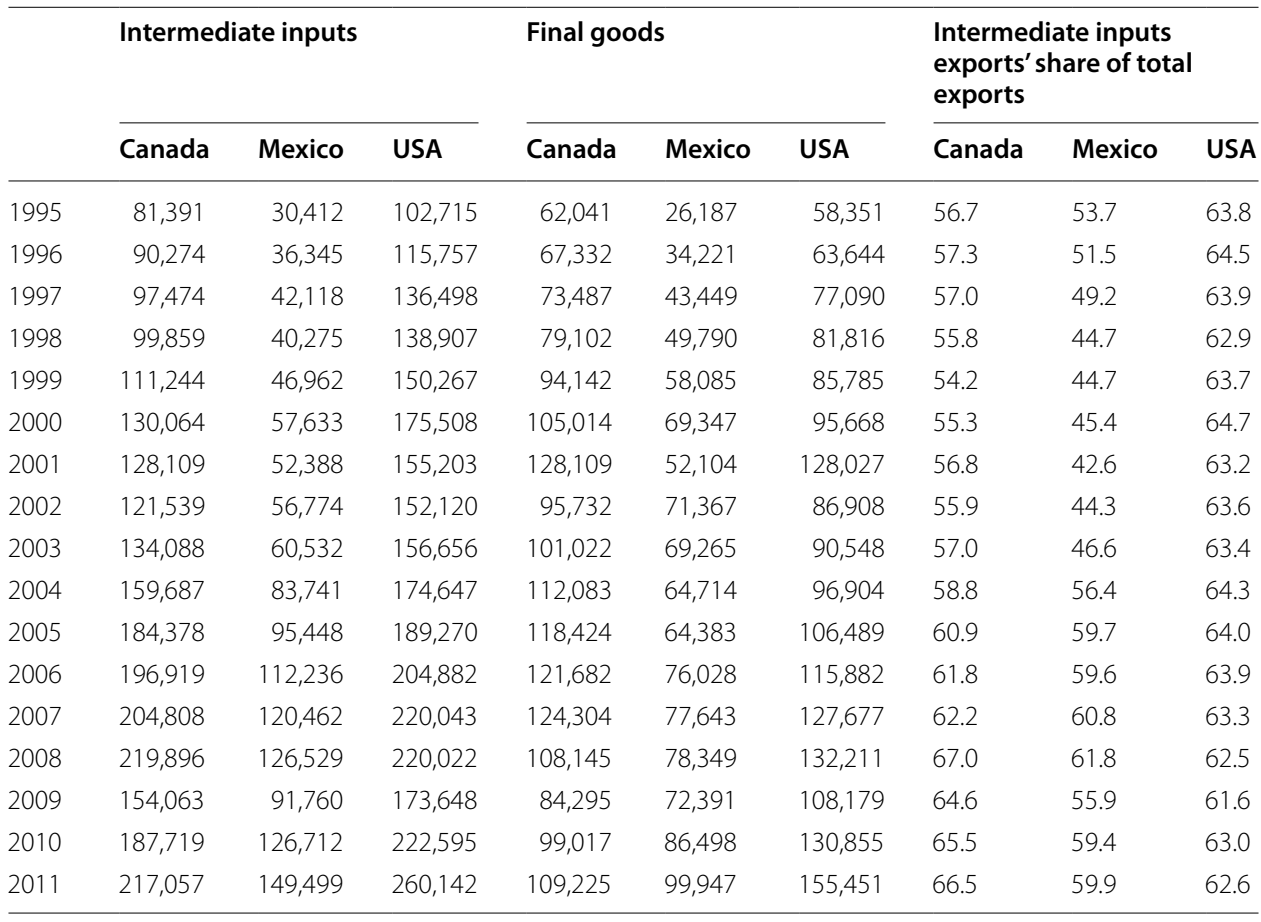

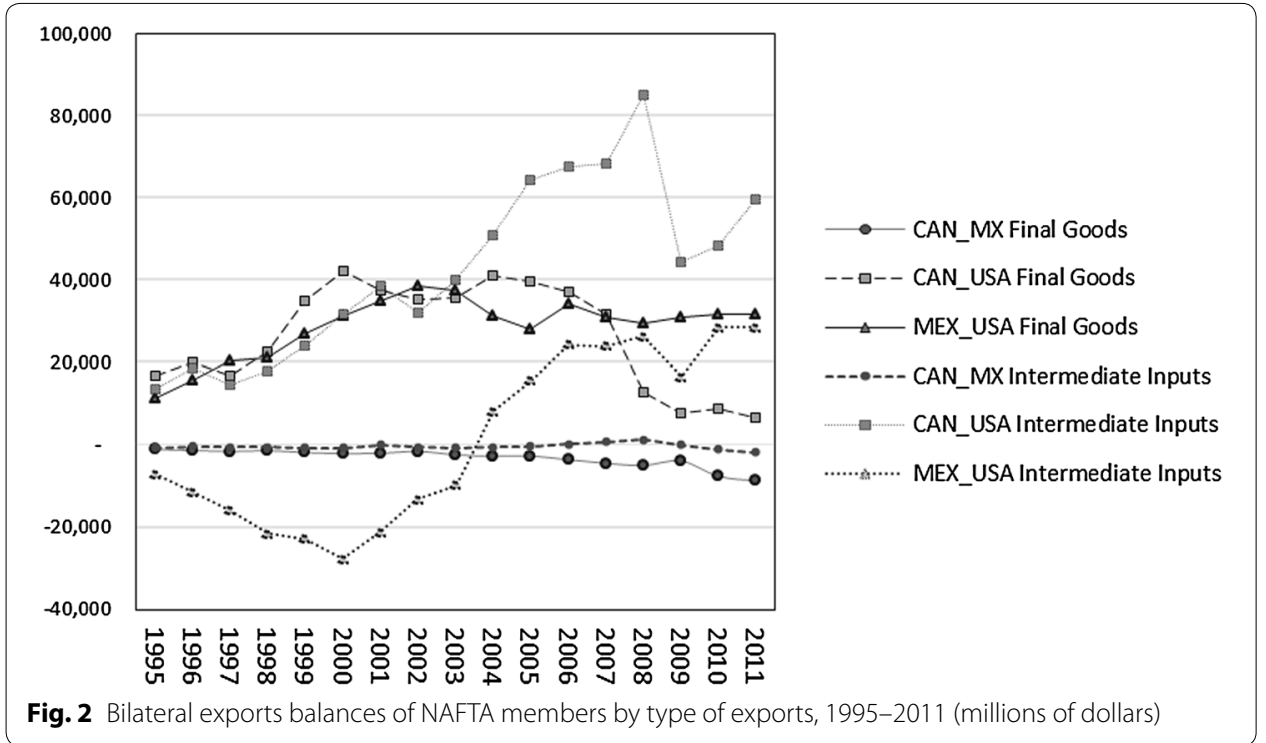

greatest volume of its exports are from intermediate goods as manufactures, but differently from the USA, such volume is much more concentrated toward the export of midtechnology and natural resources-based manufactures.

These trade patterns between NAFTA members not only illustrate the kind of trade derived from vertical specialization, but that it is possible from a given form of task distribution in the productive process to generate the gains from trade. The latter being, 
Table 2 Exports' share by type of products, 1995-2011 (average) Source Authors' estimations based on WIOD

\begin{tabular}{llll}
\hline & Canada & Mexico & USA \\
\hline Intermediate inputs & & & \\
Primary goods & 11.2 & 14.2 & 3.5 \\
Manufacturing & 41.6 & 36.3 & 51.3 \\
A. Manufacturing industries based on natural resources & 12.5 & 2.2 & 8.5 \\
$\quad$ B. Medium-tech manufacturing industries & 16.3 & 9.1 & 19.5 \\
C. High-tech manufacturing industries & 11.8 & 21.7 & 22.8 \\
$\quad$ D. Manufacturing, Nec; Recycling & 1.0 & 3.3 & 0.5 \\
Other exports & 6.9 & 2.2 & 8.7 \\
Final goods & & & \\
Primary goods & 1.3 & 1.0 & 0.6 \\
Manufacturing & 37.4 & 44.5 & 34.5 \\
A. Manufacturing industries based on natural resources & 6.1 & 7.5 & 7.1 \\
B. Medium-tech manufacturing industries & 4.3 & 1.8 & 3.5 \\
C. High-tech manufacturing industries & 24.8 & 34.0 & 22.4 \\
D. Manufacturing, Nec; Recycling & 2.3 & 1.2 & 1.4 \\
Other exports & 2.5 & 0.8 & 2.3 \\
Total & 100 & 100 & 100 \\
\hline
\end{tabular}

according to Gereffi (2014), a U form pattern for the relationship between tasks or stages of the productive process and the generation of value added, a pattern that would also be subject to changes derived from technological development, but that actually indicates that the first stages of the productive process involve research and development, other products design, and purchasing logistics; in this order the value added goes from more to less until reaching the tasks that remunerate the less to the factors of production which would be the actual production tasks (transformation) and assembling so that once the products are made, the logistics of selling (distribution), marketing, and after-purchase service start to generate more value added. In the following section, a description of the methods used to break down the value of exports intra-NAFTA in terms of value added and by country of origin of the factors of production, is given. And, in the next sections we will focus on the difference between the bilateral balances in gross exports and in value added, since for Mexico most of its volume of commerce is intra-NAFTA, in order to show that even if the gross balances of trade and the valueadded balances are only different in bilateral terms; these differences could be important in place and time for economies that are mostly integrated to one partner.

\section{Methods}

\subsection{Value-added and employment content in trade}

The method employed for the content of value added, its distribution, and the content of employment, in direct and indirect exports, between the NAFTA members follows the traditional input-output analysis based on demand. As a starting point, a set of fixed proportion production functions is used through which it is assumed that, for each product is necessary a unique combination of intermediate inputs, raw materials and components, labor and capital, so that there is no substitution between inputs or factors of production. It is considered that, for a given period, satisfying the demand implies a 
set of intermediate transactions and payments to the factors of production. Also, since it is a demand model, the method employed does not explain the value-added content in terms of changes in productivity, economies of scale, or market power. The method is just an approximation to the description of what happened, assuming that the market conditions were given and that any observed change in the generation of value, labor content, as well as other inputs could be explained by the changes in the demand and/ or in the supply. In research conducted by Ferrarini (2011), Timmer et al. (2015), and Erumban et al. (2011), the authors show in detail how the method employed here represents the GVCs as a geographical and sectorial model of value distribution of the final production.

For countries like China and Mexico, estimation and analysis of value-added content in exports have been performed by Chen et al. (2005), Cheng et al. (2008), He and Zhang (2010), Koopman et al. (2008), Lau et al. (2006), Los et al. (2012), De la Cruz et al. (2011), Larudee (2012), Fujii and Cervantes (2013a, b), and Shafaeddin and Pizarro (2010). From all the latter research, it can be argued that for China, as well as Mexico, there is a significant difference between exports value and value added, generated in their national economies as a consequence of the use of imported inputs. Furthermore, trade balances between two or more economies in terms of national value added have not been thoroughly explored yet. Lau et al. (2006) presented the estimation of the trade relationship between China and the USA in which it is found that, after discounting the value of imported direct and indirect inputs found in trade flows between both countries, the trade deficit of the USA with China would be about 4-5 times lower. ${ }^{4}$ Moreover, Johnson and Noguera (2012) estimate bilateral trade in terms of value added for 94 countries and regions, finding that: (1) the range of coefficients of national value added of a country's exports varies significantly among countries; (2) as a consequence, bilateral trade balances in terms of value added tend to differ from those measured by traditional means and; (3) in the context of this research, "Looking at the U.S.... (its) Value added exports to Canada are $\$ 77$ billion (40\%) smaller than gross exports, and value added exports to Mexico are $\$ 40-\$ 50$ billion (36-44\%) smaller." (Johnson and Noguera 2012: 233). But, according to the estimations made by the same authors, the trade deficit of the USA with Canada of almost 40 billion dollars, in gross terms, would be about 35 billion dollars in value-added terms; while for Mexico this would go from a 10 billion dollars deficit to about 4 billion surplus in value-added terms, in 2004 (Johnson and Noguera, 2012: 234, Fig. 4). Sthehrer (2012) also finds that the US trade deficit with the rest of the world will be explained differently in terms of value added than in gross terms, and he also explains the conceptual differences between the analysis of "trade in value added" (TiVA) and the "value added in trade" (VAiT) that are found in the literature, which we will latter discuss.

Finally, Benedetto (2012) and Stehrer (2012) point out that the estimations of trade flows in terms of value added do not strictly modify the total amounts of trade balances, given that, for example, if the national value-added content of exports of China is less

\footnotetext{
${ }^{4}$ Their methodology is based on an estimation of the national value added content in exports from the USA to China and vice versa. The latter results in the fact that, in average, between 2002 and 2005, the percentage of national value added contained in exports from the USA to China was $87.3 \%$, while the percentage of national value added content of exports from China to the USA was 36.8 .
} 
than the gross value of their exports, the foreign value-added content of imports of China as final goods, would also be less. Hence, the methodology used in this research only allows to eliminate the problem of double accounting in the trade flows among NAFTA members; at the time that "true gains from trade" are estimated between the three nations, locating geographically and by sector the areas in which the value added integrates gradually to final value of the products sold; so that the model used is an ex post distribution model of the production value.

With data from the World Input Output Database (WIOD) on the total transactions matrices for all the available years of the period from 1995 to 2011, the international merchandise flow is considered, distinguishing the ones that will be integrated in other processes from those that satisfy the final demand volume, according to the origin and destination by industry and country. From these transaction matrices the direct requirement matrices are derived, $\mathrm{B}_{t}$; assuming that it is the final demand of goods and services, $\mathbf{f}_{t}$, the one determining (in the short run) the gross volume of production, $\mathbf{y}_{t}$ :

$$
\mathbf{y}_{t}=\left(\mathrm{I}-\mathrm{B}_{t}\right)^{-1} \mathbf{f}_{t}
$$

where $\mathbf{y}_{t}$ is a vector of the gross value of production by industry/country of origin, for period $t, B_{t}$ is a squared matrix with a dimension of $n$ countries by $m$ industries, in which each element represents the proportion of direct input of industry $i$, country $p$ incorporated in the production of industry $j$, in country $q$, and $\left(\mathrm{I}-B_{t}\right)^{-1}$ is the known Leontief inverse. The problem of double accounting of the national and international trade flows is solved by using a value-added matrix by industry sector and country of origin (residence) of the factors of production:

$$
\mathrm{WVA}_{t}=\left(V_{t}\left(I-B_{t}\right)^{-1}\right) F_{t}
$$

where $\mathrm{WVA}_{t}$ is a squared matrix where elements represent the value added generated in each industry in each country by the volume of the final demand. $V_{t}$ is a diagonal matrix of value-added coefficients, and $F_{t}$ is the diagonal matrix of final demand by country of origin/destination. For this research, a breakdown of the final demand matrix, $F_{t}$, into matrices of final demand that NAFTA members satisfy, by either domestic consumption or demand from the rest of the world and final good exports matrices intra-NAFTA, is made. Equations (3) through (11) represent the value added generated directly or indirectly in industry $i$, country $p$, the final demand that directly satisfies the final production of each NAFTA member, and the direct exports of final goods between them:

$$
\begin{aligned}
& \text { WVA }_{\text {can }, \mathrm{t}}=\left(V_{t}\left(\mathrm{I}-B_{t}\right)^{-1}\right) F_{\text {can }, \mathrm{t}} \\
& \text { WVA }_{\text {mex }, \mathrm{t}}=\left(V_{t}\left(I-B_{t}\right)^{-1}\right) F_{\text {mex }, \mathrm{t}} \\
& \text { WVA }_{\text {usa }, \mathrm{t}}=\left(V_{t}\left(I-B_{t}\right)^{-1}\right) F_{\text {usa }, \mathrm{t}} \\
& \text { WVA }_{\text {can_mex }, \mathrm{t}}=\left(V_{t}\left(I-B_{t}\right)^{-1}\right) E_{\text {can_mex }, \mathrm{t}}
\end{aligned}
$$




$$
\begin{aligned}
& \mathrm{WVA}_{\text {can_usa,t }}=\left(V_{t}\left(I-B_{t}\right)^{-1}\right) E_{\text {can_usa, } \mathrm{t}} \\
& \mathrm{WVA}_{\text {mex_can,t }}=\left(V_{t}\left(I-B_{t}\right)^{-1}\right) E_{\text {mex_can, } \mathrm{t}} \\
& \mathrm{WVA}_{\text {mex_usa,t }}=\left(V_{t}\left(I-B_{t}\right)^{-1}\right) E_{\text {mex_usa, } \mathrm{t}} \\
& \mathrm{WVA}_{\text {usa_can,t }}=\left(V_{t}\left(I-B_{t}\right)^{-1}\right) E_{\text {usa_can, } \mathrm{t}} \\
& \mathrm{WVA}_{\text {usa_mex,t }}=\left(V_{t}\left(I-B_{t}\right)^{-1}\right) E_{\text {usa_mex, } \mathrm{t}}
\end{aligned}
$$

in which the subindices can, mex and usa in the value-added multiplier matrices, WVA, represent the country of "origin" of the finished goods. Thus, for example, in Eq. (3), $F_{\text {can, } \mathrm{t}}$ is the diagonal matrix of world final demand that it is satisfied with final goods from Canada, therefore, from the value-added matrix , $\mathrm{WVA}_{\mathrm{can}, \mathrm{t}}$, for all the set of rows for which $p=$ mex and $p=$ usa, the value added generated in these countries is added in order to obtain the total intermediate inputs exports that these countries sell to Canada, in terms of value added. Since we are considering all the direct and indirect effects that the final production of a NAFTA member will have in the value-added generation of the other two members, with these estimations our results differ from those found in Stehrer (2012). And the importance of those differences is that if the method for calculating the value added of intermediate inputs exports accounts for direct and indirect exports, this could imply a limitation for the interpretation of the advantages derived from NAFTA for each of its members. The latter since it is possible that some of the Mexican valueadded content in the gross value of Canadian final production is a consequence of selling intermediate inputs to a non-NAFTA country which in turn re-exports as an intermediate input (the Mexican product plus more inputs and value added), and then in Canada the final product is finished. As it will be shown in the next section, considering the total indirect effects widens the difference between the gross bilateral balances of trade and the value-added bilateral balances, mostly because of the way each NAFTA member is integrated with the rest of the world.

Furthermore, from Eqs. (6) to (11), the value-added matrices generated indicate the total value-added content (direct or indirect) of the final goods exports between NAFTA members. Therefore, for example, in Eq. (6) the diagonal matrix of final goods exports from Canada to Mexico, $E_{\text {can_mex, }}$, by rows, indicates the value added generated by industry and country that participates in the final goods value chain exported to Mexico from Canada. In this matrix for all $p \neq$ can the total value added generated directly or indirectly as industries/countries that export intermediate inputs, is accounted for.

In order to obtain the bilateral and total trade balances of trade flows between NAFTA members in terms of value added, in Eqs. (1) to (3) the total value added is added for both countries members of NAFTA that are not the final producer; while in Eqs. (6) to (11) only the value added of the country that exports the final goods is considered. 


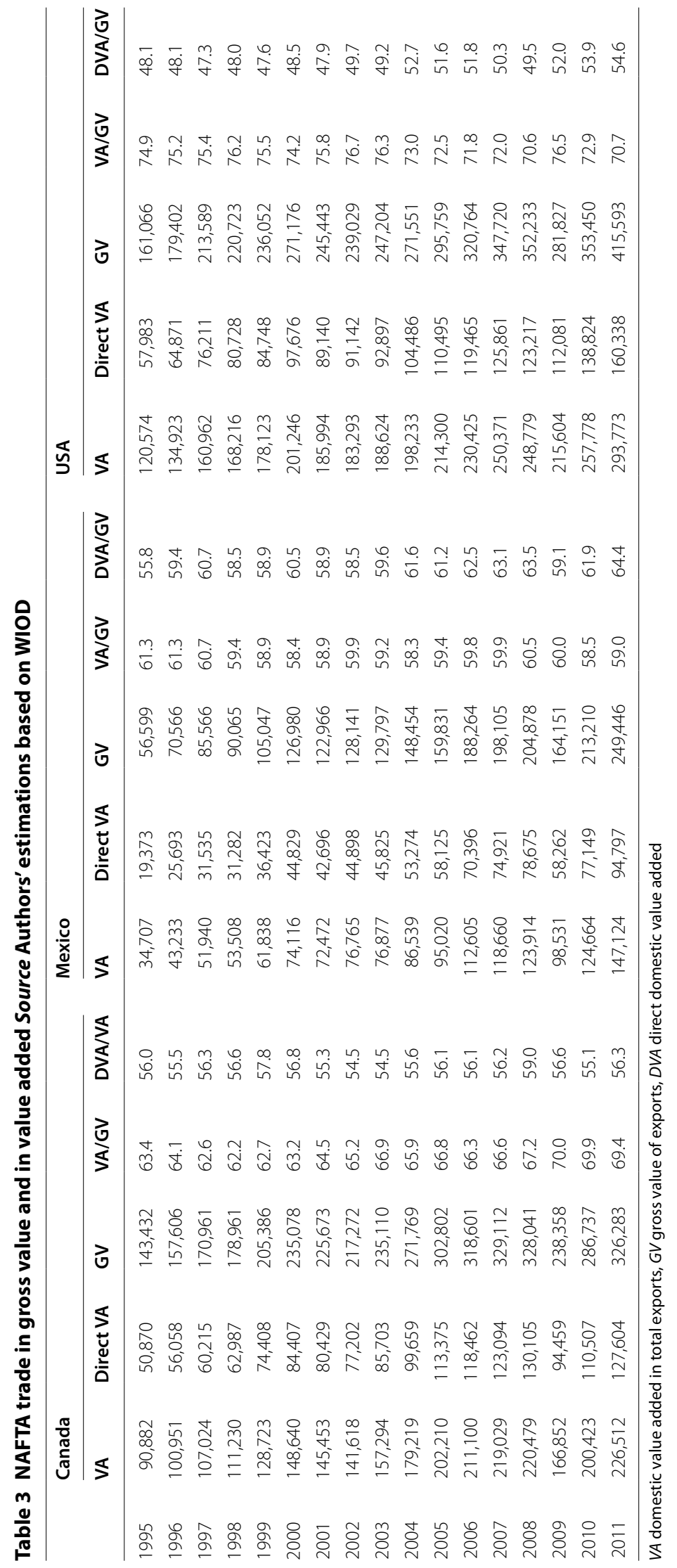


The labor content analysis, such is estimated in the same way the value added of intraNAFTA trade flows was estimated; by substituting in Eqs. (3) to (11) the diagonal matrices of value-added coefficients, $V_{t}$, by diagonal matrices of labor coefficients , $\mathrm{L}_{t}$, which are obtained from dividing the total amount of persons engaged in production by industry and country of origin between the gross product of the respective industry. For the latter the WIOD socioeconomic statistics ${ }^{5}$ were used and also, from these data, estimations of the distribution of value added between compensations to capital, labor and labor by skill levels, were performed. In the following sections results for the entire above are presented.

\section{Results and discussion}

\subsection{Balance of trade in value added and its factorial distribution}

Considering that, for all of its members the singing of NAFTA could bring direct and indirect effects into the domestic economies, in this paper we choose an estimation of the trade balances in terms of value added that represents a broader estimation than the estimations known as Trade in Value Added (TiVA) that measure "the value added of a particular country $r$ (that) is contained in consumption $\left(f^{\Im}\right)$ of another country $s$ " (Stehrer 2012: 2) and the estimations of bilateral balances of Value Added in Trade (VAiT) that exclude the indirect effects through third parties.

In Table 3 the results of estimating trade flows between NAFTA members compared with the measurement of these flows in terms of their gross values show that, if other countries are involved in the production of goods and services, the differences in the proportions of intermediate inputs that come from the rest of the world, provoke that for trade between Mexico, Canada, and the USA, in average, the value-added proportion over the gross value of exports to be less for Mexico and Canada. For the whole period, in average, the value added of the USA as a proportion of its own exports equals $74.1 \%$, while for Canada and Mexico these proportions are 65.7 and 59.6\%, respectively. However, between 1995 and 2011, for Mexico and the USA a slight trend toward a lesser content of domestic value added in their exports is present; for Canada the opposite can be observed; the latter since, as observed in Fig. 2, toward the end of the period most of Canada's surplus with the USA was explained by a trade surplus of intermediate inputs. It is worthnoting that on average, the highest share of direct domestic value added content in exports corresponds to the Mexican economy.

Figure 3 shows that the bilateral trade balances can change significantly when measured in terms of value added. As for the trade relationship between Mexico and the USA, the increasing surplus of Mexico in reality represents a deficit in terms of value added for the period of 1995-2003. Given that in both countries exports, intermediate inputs from Mexico and the USA can be present, if the gross value balance was 4276 million dollars in favor of Mexico in 1995, in value added the balance was of 4561 million dollars in favor of the USA, the latter without considering the possibility that the compensations to capital contained in the domestic value added can be due to foreign capital. Toward

5 The socioeconomic statistics in WIOD lack several data for some economies, for the years 2010 and 2011, so we use the 2009 coefficients whenever there was data missing. 


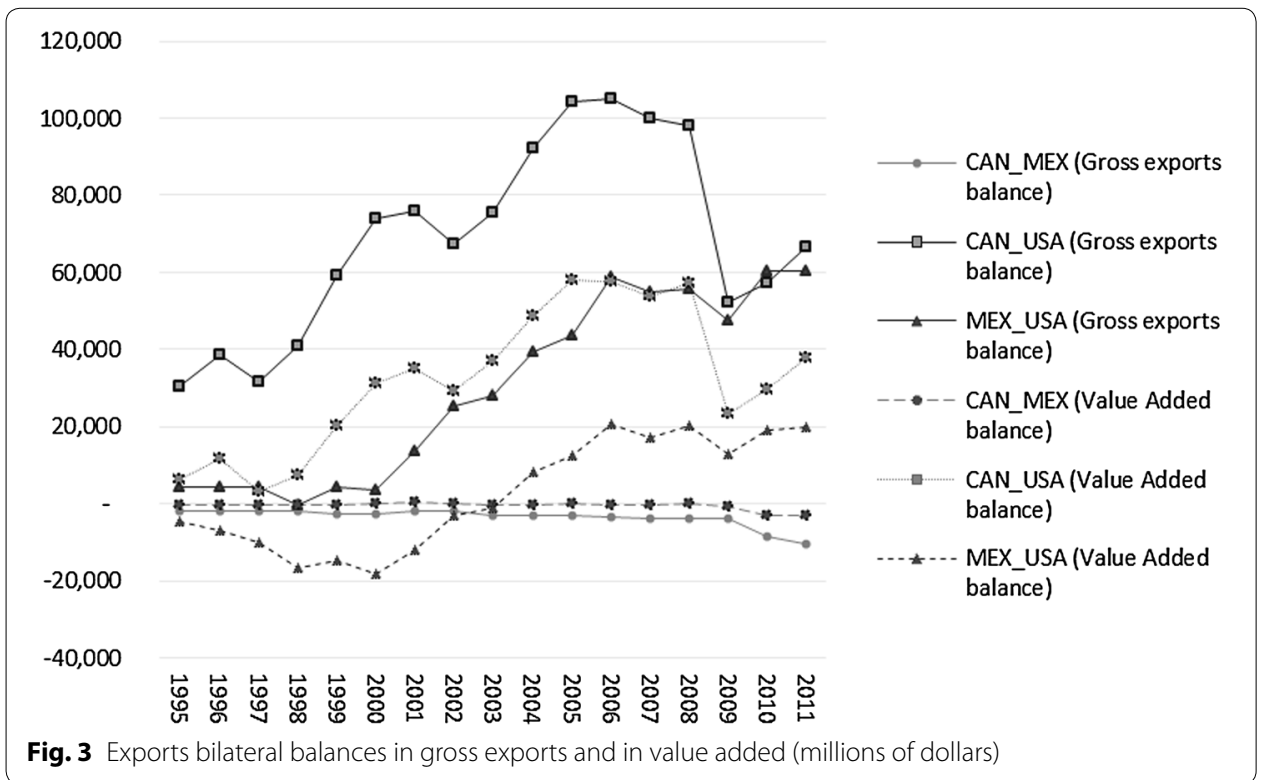

2011, the corresponding amounts were 60,211 million dollars of surplus for Mexico in gross value and 19,901 in terms of value added.

As for the bilateral trade balance between Canada and the USA, it can also be observed that the surplus in favor of Canada is less in terms of domestic value added and that, toward the end of the period, the gap between both surpluses tends to close, the latter can be attributed to either the increase in the incorporation of intermediate inputs produced in Canada or, as previously observed, the increase in the surplus of Canada with the USA explained by the trade surplus of intermediate goods.

The trade relationship between Mexico and Canada also changes when the analysis is made in terms of value added, given that the Canadian trade deficit in 1995 of 1692 million dollars was reduced to 488 million dollars in terms of value added, and in 2011, the gap between deficits for Canada widened from 10,386 million dollars in gross value terms to 3195 in value-added terms.

The general trade balance for the three NAFTA members, once the double accounting in trade flows is eliminated, shows that between 1995 and 2011, according to the estimations performed in this research, the value added generated by the Mexican and Canadian economies would have been less than the value added generated in the rest of the world. ${ }^{6}$ Even more, it can be observed that, even for some subperiods (2000-2001, 2003-2008, and 2010-2011), the value added generated in the USA would also be less than the one generated by the rest of the world (see Fig. 4).

Additionally, considering that in the shared international production, multinational companies participate, especially in economies like the Mexican one, breaking down the value added in compensations to capital and labor allows to further advance in defining the type of prerequisites that must be fulfilled in order for exports growth to translate

\footnotetext{
${ }^{6}$ In these value added estimations for the rest of the world an estimation of the international transport margins is included together with the net tax balance for all the countries involved, so the domestic value added for each country is to be interpreted only as payments to factors of production.
} 


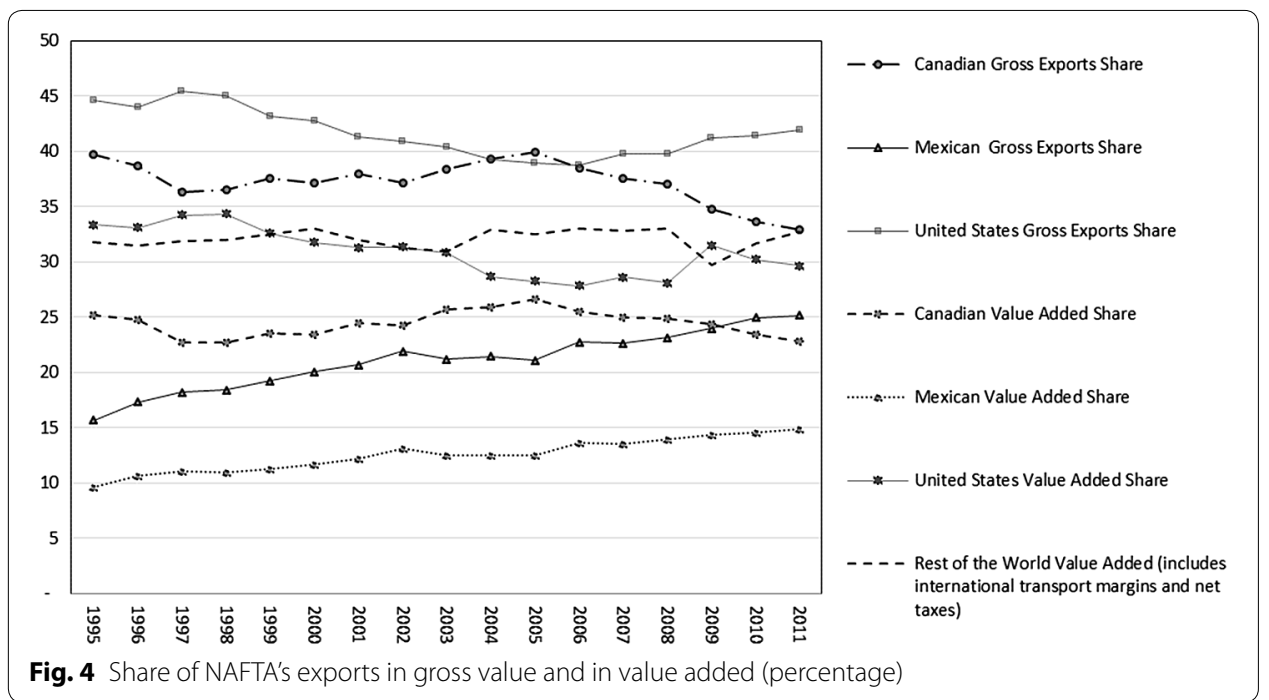

into economic growth. That is, considering that the multiplier effect of exports assumes that the income generated by these exports equals an increase of the domestic demand of consumption and/or capital, once the intermediate inputs content of imported origin plus the marginal propensity to import consumption goods and capital is discounted; it must be considered that the compensations to capital to which multinational companies are entitled to, could be brought back to the country, spent or saved in different economies to the one directly exporting; such that it is the compensations to labor the ones that come back to the system in the form of consumption goods and savings.

These results in the estimation of the bilateral balances in terms of value added seem quite unfavorable for the Mexican economy, especially as it is shown in Table 4 and Fig. 5, for China and India although there are wider gaps between their trade surplus with the USA in gross exports and in value added, in millions of dollars, on average these gaps are relatively smaller. And, again the main difference between our estimations and the ones presented in Johnson and Noguera (2012) and Stehrer (2012) is that we account for some indirect exports from the NAFTA members through a third country that might be a NAFTA member or not. Therefore, since the Mexican economy is less integrated to the rest of the world than the US and Canadian economies as an intermediate input supplier, in our estimations the Mexican surplus with the USA in value added in 2005 equals 12.5 billion dollars while in Stehrer equals 36.1 billion (Stehrer 2012: 12).

For the factorial distribution of domestic value added due to trade flows between NAFTA members, Fig. 6 shows the estimation results of the compensations to capital and labor as proportions of the gross value of the total of exports. As can be observed, first, most of the participation percentages correspond to compensations to labor in the USA, with a diminishing trend throughout the whole period. Second, the lowest participation in the distribution of value added corresponds to the compensations to labor in Mexico. Both for the USA and for Canada during the whole time period considered, compensations to labor are larger than the compensations to capital, and for Mexico the opposite can be said. In average, a little more than $18 \%$ of exports value added between the three members corresponds to labor compensations in the USA, 13.3\% of 


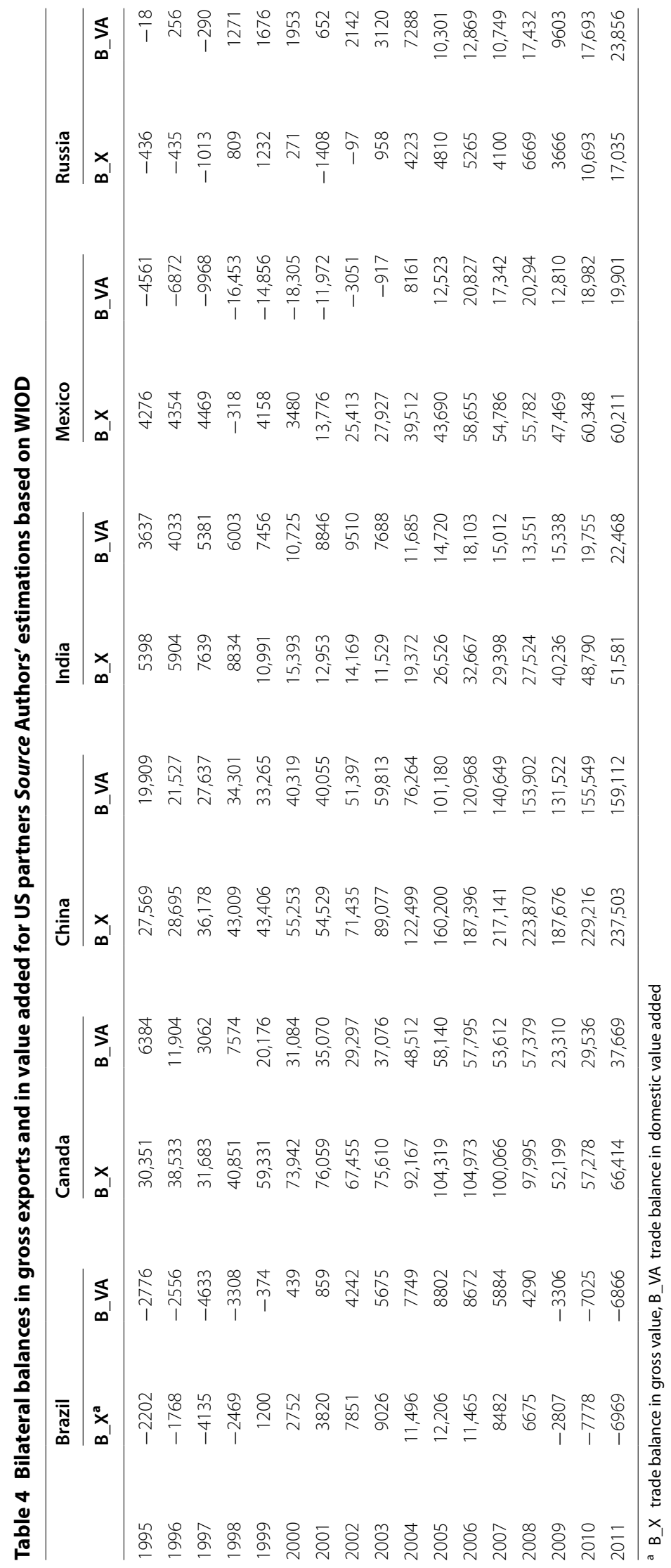



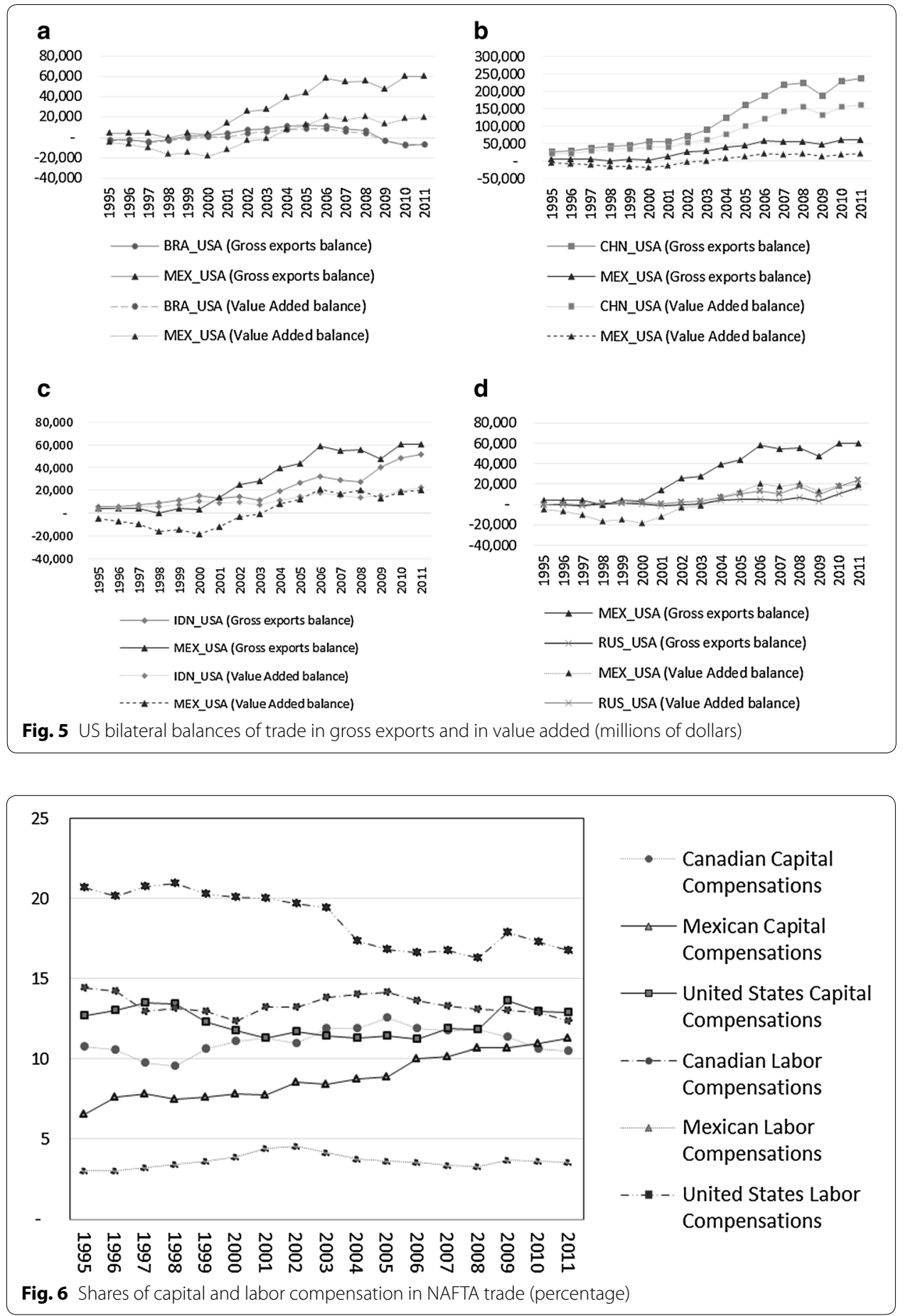

labor compensations in Canada, and 3.1\% for Mexico. Furthermore, in Mexico the gap between labor and capital compensations widens throughout the period considered. Even though it is not one of the objectives of this research to empirically link such distribution to the households consumption goods demand and the companies investment goods demand, two main aspects of this distribution pattern must be considered when linking theoretically the benefits from trade liberalization and economic integration 
with economic growth: (1) as mentioned before, for developing countries such as Mexico, a significant volume of its exports is made by transnational companies that can (or not) decide on whether to bring back their utilities in order to reinvest them in different economies; (2) low levels of labor compensations derived from export activities may have an insignificant impact on the effective domestic demand; so that this "re-flow" of income do not guarantee that exports will constitute the main drive for economic growth in emerging economies.

By skill level, labor compensations directly and indirectly generated by trade flow between NAFTA members show a distribution pattern that tends to compensate medium-skilled labor in the three countries. For American workers, throughout the whole period, a tendency toward a larger participation of labor compensations for highskilled workers can be observed. The lower compensations are for low-skilled workers in Canada and Mexico, followed by highly skilled workers in Mexico and low-skilled workers in the USA (Fig. 7).

\subsection{Number of persons engaged in NAFTA and labor compensations per hour by skill levels}

Regarding the number of individuals involved in trade between Mexico, Canada, and the USA, Figs. 8 and 9 show the total volume by country and the per capita value added derived. As expected, the larger volume of individuals (workers and owners) can be found in the Mexican economy and with an increasing trend slightly greater than one of its commercial partners throughout the whole time period considered. That is, if by the beginning of the period, the total amount of individuals directly and indirectly involved in intra-NAFTA trade was about 7.4 million, of which $46.4 \%$ resided in Mexico, toward 2011 of the 9.8 million involved, 56.4\% (5.5 millions) resided in Mexico.

The relatively larger growth of employment associated with NAFTA trade in Mexico, however, did not translated into a fall in per capita value added; that is, even though throughout the whole period, per capita value added in Mexico was the lowest, with

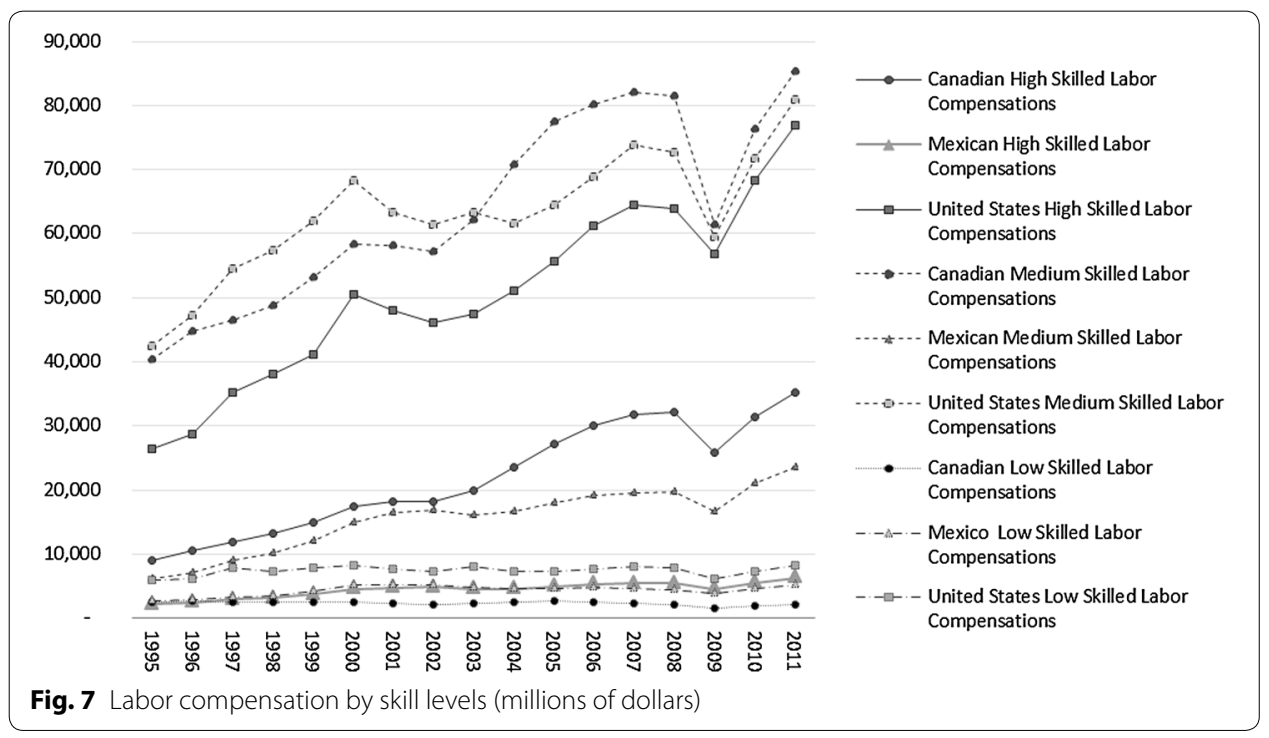



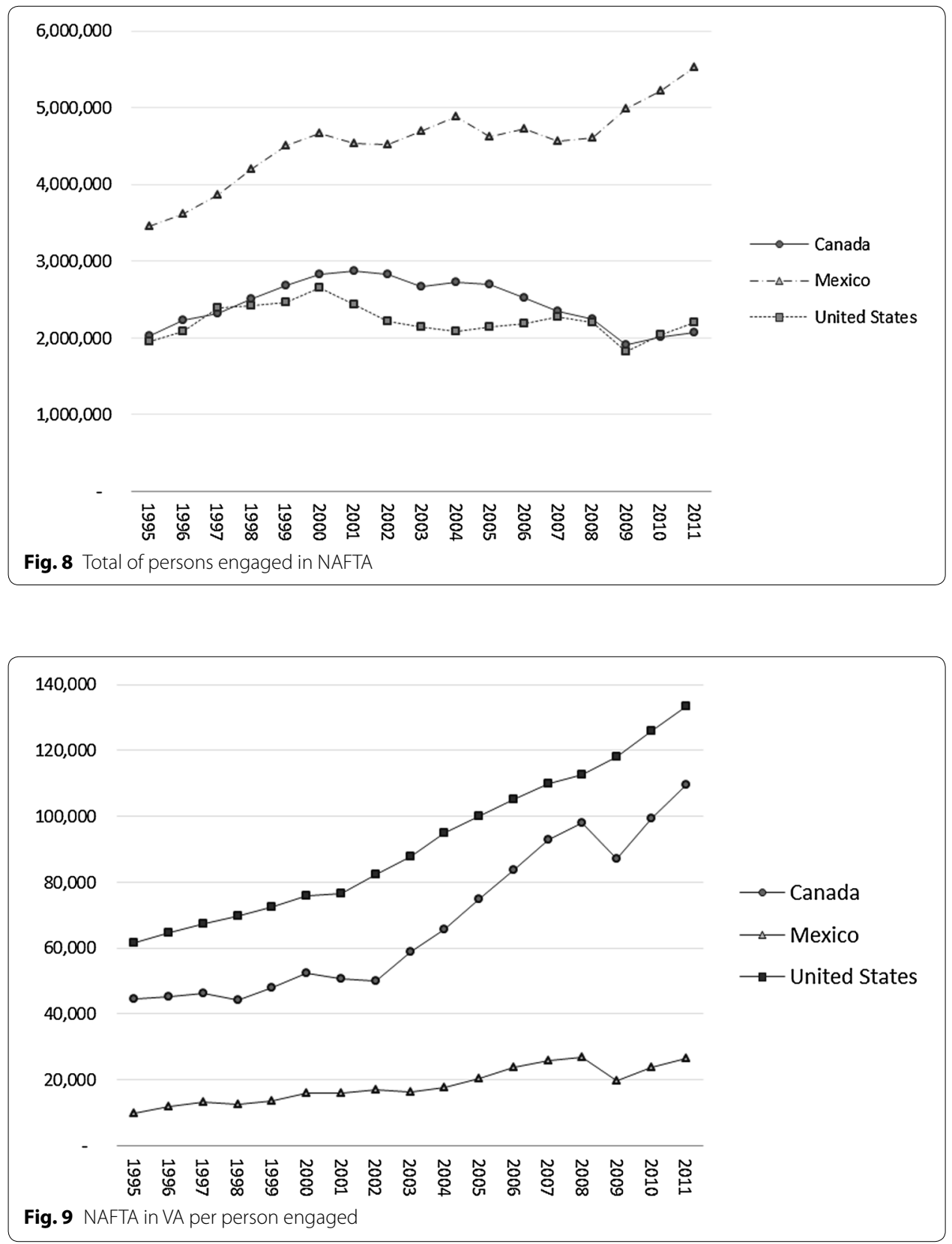

10,053 dollars in 1995 and 26,592 dollars in 2011; in comparison with the 61,725 and the 120,574 dollars of per capita value added in Canada and the USA, respectively, in 1995 and the 226,512 and 293,773 dollars in 2011: Per capita value added in Mexico went from being almost 6.4 times lower than the one generated in the USA in 1995 to be 5 times lower in 2011. As for the Canadian per capita value added, a reduction in the per capita value-added gap relative to the one generated in the American economy can be observed.

In contrast, the average labor compensation per hour grew throughout the whole period, given the median compensations by industrial sector and the intra-NAFTA trade characteristics. As shown in Table 5 and Fig. 10, for the whole period, the highest 
Table 5 Labor compensations per hour and skill levels, 1995-2011 Source Authors' estimations based on WIOD

\begin{tabular}{llllllllll}
\hline & $\begin{array}{l}\text { Canada_ } \\
\text { HS }\end{array}$ & $\begin{array}{l}\text { Mexico_} \\
\text { HS }\end{array}$ & $\begin{array}{l}\text { United } \\
\text { States_ } \\
\text { HS }\end{array}$ & $\begin{array}{l}\text { Canada } \\
\text { MS }\end{array}$ & $\begin{array}{l}\text { Mexico_- } \\
\text { MS }\end{array}$ & $\begin{array}{l}\text { United } \\
\text { States_- } \\
\text { MS }\end{array}$ & $\begin{array}{l}\text { Canada_LS } \\
\text { LS }\end{array}$ & $\begin{array}{l}\text { Mexico_ } \\
\text { LS }\end{array}$ & $\begin{array}{l}\text { United } \\
\text { States_LS }\end{array}$ \\
\hline 1995 & 16.41 & 3.48 & 28.68 & 13.25 & 2.04 & 16.89 & 10.21 & 0.68 & 11.90 \\
1996 & 17.21 & 3.61 & 29.07 & 13.33 & 2.14 & 17.37 & 10.19 & 0.70 & 12.09 \\
1997 & 18.26 & 4.09 & 30.39 & 13.32 & 2.39 & 17.74 & 10.21 & 0.82 & 12.83 \\
1998 & 17.81 & 4.14 & 31.86 & 13.01 & 2.44 & 18.44 & 9.67 & 0.82 & 12.66 \\
1999 & 18.88 & 4.54 & 33.82 & 13.22 & 2.68 & 19.56 & 9.78 & 0.91 & 12.93 \\
2000 & 19.65 & 5.24 & 37.38 & 13.87 & 3.15 & 19.87 & 10.20 & 1.11 & 13.25 \\
2001 & 19.61 & 5.56 & 39.07 & 13.71 & 3.40 & 20.67 & 10.28 & 1.20 & 13.72 \\
2002 & 19.97 & 5.75 & 40.50 & 13.78 & 3.48 & 22.07 & 9.83 & 1.23 & 13.89 \\
2003 & 22.78 & 5.19 & 43.23 & 16.10 & 3.16 & 23.53 & 11.48 & 1.09 & 15.26 \\
2004 & 25.24 & 4.99 & 45.35 & 17.89 & 2.98 & 23.76 & 12.80 & 1.02 & 15.02 \\
2005 & 28.01 & 5.46 & 47.48 & 20.17 & 3.40 & 24.41 & 14.06 & 1.13 & 15.39 \\
2006 & 31.71 & 5.81 & 50.00 & 22.56 & 3.58 & 25.12 & 15.35 & 1.20 & 15.82 \\
2007 & 34.37 & 6.01 & 50.39 & 24.92 & 3.76 & 25.95 & 17.54 & 1.19 & 16.41 \\
2008 & 36.23 & 5.83 & 51.50 & 26.13 & 3.72 & 26.17 & 18.07 & 1.12 & 16.64 \\
2009 & 33.98 & 4.72 & 52.00 & 23.61 & 2.99 & 26.52 & 15.54 & 0.89 & 16.37 \\
2010 & 39.71 & 4.71 & 52.35 & 27.76 & 3.07 & 26.73 & 18.18 & 0.90 & 16.57 \\
2011 & 43.35 & 4.75 & 52.20 & 30.33 & 3.12 & 26.69 & 19.82 & 0.90 & 16.52 \\
\hline
\end{tabular}

HS high-skilled workers, MS medium-skilled workers, LS low-skilled workers

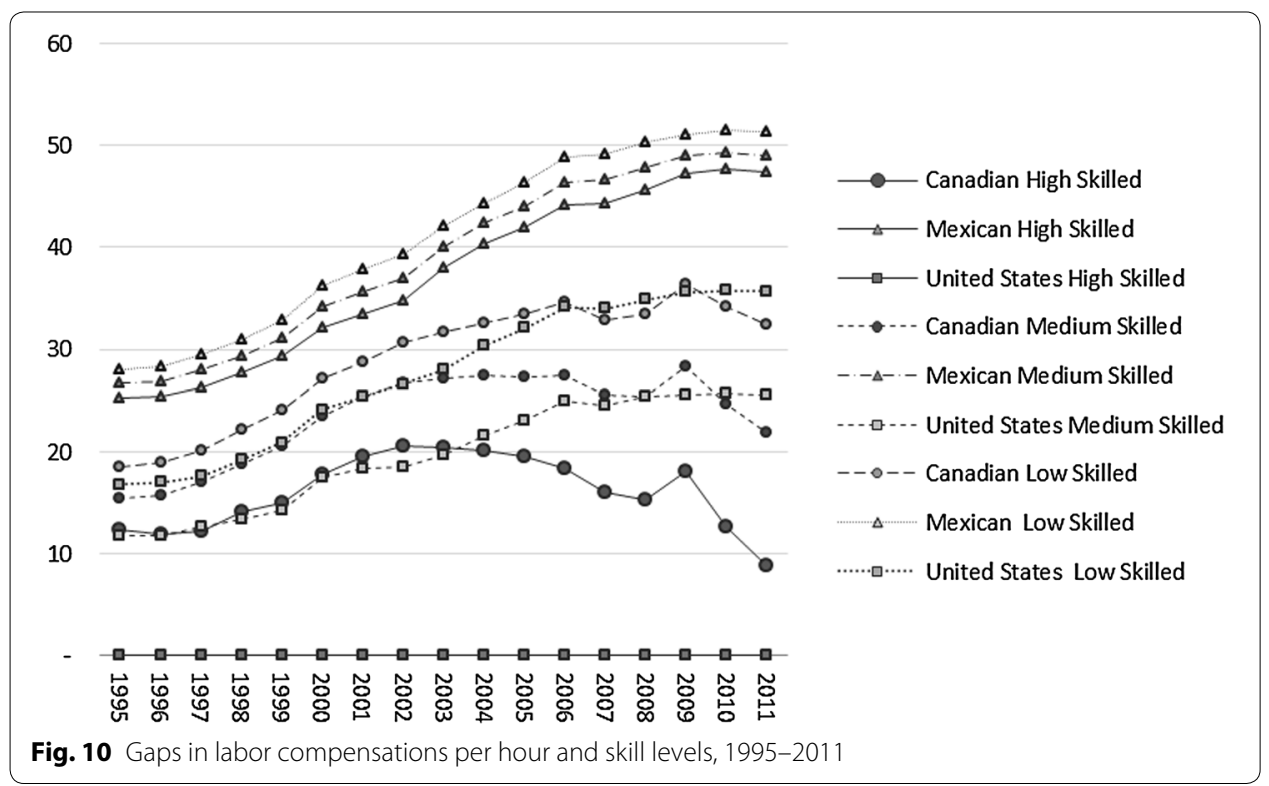

average compensation per hour was that of the highly skilled American workers, followed by the average compensation per hour of the highly skilled Canadian workers and the medium-skilled American workers. The lowest average compensations per hour are for the Mexican workers. Regarding the gap of the average per hour compensations between the highly skilled American workers and the rest, only toward the end of the period the Canadian workers would be closing such gap. As for the Mexican workers, a 
constant growth of the gap between their hourly income and the average per hour compensation of the highly skilled American workers can be observed.

Hence, given the available data and the methodology used, trade among NAFTA members did not reduce the inequality between the median remunerations of workers. Assuming that each of the countries had different relative endowments by level of skill and that there were no structural changes in such endowments, derived from free trade, it was expected for the gaps to close. Thus, the reason for the latter to not be observed can be attributed to economic, institutional, and governability factors of those countries that are not considered in this research, but that should be included in further work in order to find an explanation to the fact that the working conditions of Mexican laborers has not improved even in the wake of the enacted reforms and the expansion of international trade.

\section{Conclusions}

From the analysis presented in this research the following final remarks are put forward:

1. Both for Mexico and for Canada, their recent commercial surpluses with the USA are significantly different in terms of value added. In fact, for the Mexican economy, in the first years of NAFTA, its gross value of exports surplus with the USA was actually a deficit in terms of value added.

2. Of the trade between all three NAFTA members, throughout the whole period considered, the economy of the USA is the one with the largest proportion of domestic value-added content in its exports, in average, $74.1 \%$ of its gross exports account for domestic value added. The averages for Canada and Mexico are 65.7 and 59.6\%, respectively. Furthermore, both for the Mexican and for American economies, between 1995 and 2011 a reduction in the proportion of domestic value-added content in its exports can be observed, and the opposite can be said for Canada.

3. In the three countries, there is an evident trend for the direct value-added content of their exports to be a larger proportion of the gross value of their exports. Nonetheless, it is in the Mexican economy where the largest amount of direct value added, as a proportion of the value of its exports, can be observed.

4. The fragmentation processes of international production are so vast, that even in a free trade agreement context such as NAFTA, the value added generated in the rest of the world (indirectly) due to trade between Mexico, Canada, and the USA, is superior to the value added generated in Mexico throughout the whole period considered, and if the international margins of transport plus net taxes are considered, in fact, the value added generated in the USA could be less than the one from the rest of the world.

5. As for the distribution of value added as capital and labor payments, it can be observed that the most significant gap is the one between labor compensation paid on the USA and the compensations paid in Mexico, as a proportion of the total value of trade in NAFTA. Nonetheless, throughout the whole period, the gap tends to close, since if in 1995 the $20.7 \%$ of exports value in NAFTA represented labor compensations in the USA, in Mexico such proportion was 3.1\%, while in 2011, the proportions changed to 16.7 and $3.5 \%$, respectively. 
6. It must be highlighted that for the Canadian and American economies, labor compensations are always above (in volume) the capital compensations, for Mexico is the exact opposite.

7. By level of skill, labor compensations tend to concentrate in compensations to medium-skilled labor. However, for Canada and the USA a trend toward a larger participation of labor compensations to high-skilled labor, as proportion of the total volume of trade, can be observed.

8. Regarding the amount of individuals involved directly and indirectly in trade between NAFTA members, in Mexico is where the bulk of individuals (workers and owners) participated in the production of exports. The latter meaning a lower level of per capita value added that could imply lower gains from foreign trade considering that is this level of value added the one that could be translated in larger volumes of domestic demand that are necessary to achieve higher economic growth rates.

9. Finally, in terms of the average labor compensation per hour, by skill levels there is no evidence that the growth of commerce between Mexico and its partners had reduced the compensation gaps.

\section{Authors' contributions}

RC designed the study and its aims, wrote the very first version in Spanish, and also was responsible for the estimations and the methodological section. JV wrote the first and final versions in English, participated in the interpretation of the estimations results, and helped to solve some methodological issues. MR is responsible for the literature review regarding the theoretical framework and the expectations concerning the sign of the NAFTA. All authors read and approved the final manuscript.

\section{Acknowledgements}

The present study was sponsored by the Ministry of Public Education of Mexico (Secretaría de Educación Pública), Grant 230697, and Project 23982.

\section{Competing interests}

The authors declare that they have no competing interests.

Received: 23 July 2016 Accepted: 7 November 2016

Published online: 21 November 2016

\section{References}

Benedetto JB (2012) Implications and interpretations of value added trade balances. J Int Commer Econ 4(2):39

Cervantes R, Villaseñor J (2014) Perfil exportador de Jalisco: valor agregado nacional y local contenido en sus exportaciones manufactureras. Carta Económica Regional 113:166-200

Chen X, Cheng LK, Fung KC, Lau LJ (2005) The estimation of domestic value added and employment induced by exports: an application to Chinese exports to the United States. Paper presented at the 2005 American Economic Association Meeting, Philadelphia. 17 Chen, $X$

Cheng LK, Fung KC, Lau LJ, Sung Y, Yang C, Zhuy K, Tang Z (2008) Domestic value added and employment generated by Chinese exports: a quantitative estimation. MPRA paper no. 15663

Clavijo F, Valdivieso S (2000) Reformas estructurales y política macroeconómica: El caso de México 1982-1999. Serie Reformas Estructurales No. 67 UN CEPAL, División de Desarrollo Económico, Países Bajos

De la Cruz J, Koopman RB, Wang Z (2011) Estimating foreign value-added in Mexico's manufacturing exports. U.S. International Trade Commission, Office of Economics Working Paper, No. 2011-04A

Erumban A, Los B, Stehrer R, Timmer M, de Vries G (2011) "Slicing up global value chains". Paper prepared for the World Bank Workshop'The Fragmentation of Global Production and Trade in Value Added'. June 9-10 2011

Ferrarini B (2011) "Mapping vertical trade", ADB working paper series no. 263, Asian Development Bank

Fujii G, Cervantes R (2013a) "Mexico: value added in exports of manufactures", CEPAL Review, No. 109, April

Fujii G, Cervantes R (2013b) "Indirect domestic value added in Mexico's manufacturing exports, by origin and destination sector", Levy Economics Institute of Bard College, Working Paper No. 760

Gereffi G (2013) "Global value chains in a post-Washington Consensus world. Rev Int Polit Econ 21(1):9-37

Gereffi G (2014) "Nuevas tendencias en las cadenas de valor y el escalamiento industrial" conference presented at Seminario Sobre Cadenas de Valor de las Exportaciones Mexicanas, INEGI-UNAM, 10 de abril de 2014. http://www.inegi. org.mx/eventos/2014/exportaciones/doc/P-GaryGereffi.pdf

He D, Zhang W (2010) How dependant is the Chinese economy on exports and in what sense has its growth been export-led? J Asian Econ 21:87-104 
Johnson RC, Noguera G (2012) Accounting for intermediates: production sharing and trade in value added. J Int Econ 86:224-236

Kaplinsky R (2000) Globalisation and unequalisation: what can be learned from value chain analysis? J Dev Stud 37:117-146

Koopman R, Wang Z, Wei SJ (2008) How much of Chinese exports is really made in China? Assessing domestic valueadded when processing trade is pervasive. Working Paper 14109 NBER

Larudee M (2012) Measuring openness: VADE, not trade. Oxf Econ Stud 40:119-137

Lau LJ, Chen X, Cheng LK, Fung KC, Pei J, Sung Y, Tang Z, Xiong Y, Yang C, Zhu K (2006) Estimates of US-China trade balances in terms of domestic value-added. Working Paper No. 295, Stanford Center for International Development

List F (1997[1841]) Sistema nacional de economía política. FCE. México. 2a edición

Los B, Timmer M, de Vries G (2012) China and the world economy: a global value chain perspective on exports, incomes and jobs. Groningen Growth and Development Centre

OECD-WTO (2012) Trade in value added: concepts, methodologies, and challenges. OECD, Mimeo

Prebish R (1949) Interpretación del proceso de desarrollo latinoamericano. Serie Conmemorativa del XXV Aniversario de la CEPAL, Santiago de Chile, 1973, CEPAL

Puyana A (2003) El camino hacia el regionalismo abierto. Los acuerdos de libre comercio de México con América del Norte y Europa. CEPAL, Serie Comercio Internacional, 35

Rodríguez O (2006) El estructuralismo latinoamericano. Siglo XXI, CEPAL, Mexico, p 496

Shafaeddin M, Pizarro J (2010) The evolution of value added in assembly operations: the case of China and Mexico. J Chin Econ Bus Stud 8:373-397

Smith A (2008) [1776]) Investigación de la Naturaleza y Causa de la Riqueza de las Naciones. Fondo de Cultura Económica, México

Stehrer R (2012) Trade in value added and the value added in trade. WIOD Working Paper: 1-19. www.wiod.org Stehrer R, de Vries G J, Los B, Timmer M, and Erumban AA (2013) Slicing up global value chains. GD-135. Groningen Growth and Development Centre

Thirwall AP (2013) Kaldor's 1970 regional growth model revisited. School of Economics Discussion Papers, University of Kent, KDPE 1311

Timmer MP, Dietzenbacher E, Los B, Stehrer R, de Vries GJ (2015) An illustrated user guide to the world input-output database: the case of global automotive production. Rev Int Econ 23:575-605

United Nations Commodity Trade Statistics Database (2015) http://comtrade.un.org/db/

World Bank (2013) World DataBank: http://databank.worldbank.org/data/home.aspx

WIOD: http://www.wiod.org/new_site/data.htm

\section{Submit your manuscript to a SpringerOpen ${ }^{\circ}$ journal and benefit from:}

- Convenient online submission

- Rigorous peer review

Immediate publication on acceptance

- Open access: articles freely available online

- High visibility within the field

- Retaining the copyright to your article

Submit your next manuscript at $\gg$ springeropen.com 